\title{
An intact unfolded protein response in Trpt1 knockout mice reveals phylogenic divergence in pathways for RNA ligation
}

\author{
HEATHER P. HARDING, ${ }^{1,2}$ JEREMY G. LACKEY, ${ }^{3}$ HAO-CHI HSU, ${ }^{1,2}$ YUHONG ZHANG, ${ }^{1}$ JING DENG, ${ }^{1,6}$ \\ RUI-MING XU, ${ }^{1,2}$ MASAD J. DAMHA, ${ }^{3}$ and DAVID RON ${ }^{1,4,5}$ \\ ${ }^{1}$ Kimmel Center for Biology and Medicine of the Skirball Institute, New York University School of Medicine, New York, New York 10016, USA \\ ${ }^{2}$ Department of Pharmacology, New York University School of Medicine, New York, New York 10016, USA \\ ${ }^{3}$ Department of Chemistry, McGill University, Montreal, QC, Canada H3A 2K6 \\ ${ }^{4}$ Department of Cell Biology, New York University School of Medicine, New York, New York 10016, USA \\ ${ }^{5}$ Department of Medicine, New York University School of Medicine, New York, New York 10016, USA
}

\begin{abstract}
Unconventional mRNA splicing by an endoplasmic reticulum stress-inducible endoribonuclease, IRE1, is conserved in all known eukaryotes. It controls the expression of a transcription factor, Hac1p/XBP-1, that regulates gene expression in the unfolded protein response. In yeast, the RNA fragments generated by Ire $1 p$ are ligated by tRNA ligase (Trl1p) in a process that leaves a $2^{\prime}-\mathrm{PO}_{4}{ }^{2-}$ at the splice junction, which is subsequently removed by an essential $2^{\prime}$-phosphotransferase, Tpt1p. However, animals, unlike yeast, have two RNA ligation/repair pathways that could potentially rejoin the cleaved Xbp-1 mRNA fragments. We report that inactivation of the Trpt1 gene, encoding the only known mammalian homolog of Tpt1p, eliminates all detectable 2'-phosphotransferase activity from cultured mouse cells but has no measurable effect on spliced Xbp-1 translation. Furthermore, the relative translation rates of tyrosine-rich proteins is unaffected by the Trpt1 genotype, suggesting that the pool of (normally spliced) tRNA ${ }^{\text {Tyr }}$ is fully functional in the Trpt1-/- mouse cells. These observations argue against the presence of a $2^{\prime}-\mathrm{PO}_{4}{ }^{2-}$ at the splice junction of ligated RNA molecules in Trpt1-/- cells, and suggest that Xbp-1 and tRNA ligation proceed by distinct pathways in yeast and mammals.
\end{abstract}

Keywords: tRNA splicing; RNA ligase, 2'-phosphotransferase; translation; protein folding; mouse genetics

\section{INTRODUCTION}

Eukaryotic cells respond to the stress of protein misfolding in the endoplasmic reticulum by a signal transduction pathway that culminates in enhanced transcription of genes encoding ER chaperones (for review, see Ron and Walter 2007). In yeast, this unfolded protein response (UPR) is initiated by the ER stress-induced activation of an endoribonuclease, Irelp, that excises an internal inhibitory fragment of the HAC1 mRNA (Cox and Walter 1996; Mori et al. 1996). The two ends of the mRNA are joined together

\footnotetext{
${ }^{6}$ Present address: Dana-Farber Cancer Center, Dana-Farber Cancer Institute, 44 Binney Street, Boston, MA 02115, USA.

Reprint requests to: Heather P. Harding, Kimmel Center for Biology and Medicine of the Skirball Institute, New York University School of Medicine, SI 3-10 540 First Avenue, New York, NY 10016, USA; e-mail: harding@saturn.med.nyu.edu; fax: (212) 263-8951.

Article published online ahead of print. Article and publication date are at http://www.rnajournal.org/cgi/doi/10.1261/rna.859908.
}

by Trllp, the same enzyme that ligates endonucleolytically processed pre-tRNAs in tRNA splicing (Sidrauski et al. 1996). Unlike its precursor, the spliced HAC1 mRNA is efficiently translated into a transcription factor that activates genes encoding ER chaperones (Ruegsegger et al. 2001).

RNA ligation by Trllp entails three distinct steps: hydrolysis of the $2^{\prime}-3^{\prime}$-cyclic phosphate bond at the end of the 5'-RNA fragment, phosphorylation of the $5^{\prime}$ hydroxyl of the $3^{\prime}$-fragment (with GTP as a phosphate donor), and the joining together of the two ends in a ligation step involving an adenylated intermediate (reviewed in Abelson et al. 1998; Hopper and Phizicky 2003). These three steps leave a $2^{\prime}$-phosphate $\left(2^{\prime}-\mathrm{PO}_{4}{ }^{2-}\right)$ at the $5^{\prime}$-splice junction, which in yeast is removed by a $2^{\prime}$-phosphotransferase Tptlp, encoded by an essential gene TPT1 (Culver et al. 1997). Tptlp is an unusual enzyme that utilizes $\mathrm{NAD}^{+}$ as a cosubstrate in a reaction that generates a $2^{\prime}$ hydroxyl (restoring the RNA to its conventional structure), nicotinamide, and ADP-ribose $1^{\prime \prime}-2^{\prime \prime}$ cyclic phosphate (Appr $>\mathrm{p}$ ) 
(Culver et al. 1993). Genetic and biochemical studies have shown that removal of the residual $2^{\prime}-\mathrm{PO}_{4}{ }^{2-}$ from ligated RNAs is the only essential function of yeast TPT1 (Schwer et al. 2004), and that Irelp-induced HAC1 mRNA splicing entails all the enzymatic steps described above (Gonzalez et al. 1999).

IRE1 is conserved in other eukaryotes (Tirasophon et al. 1998; Wang et al. 1998), as is its function to cleave a preexisting mRNA in ER stressed cells (Yoshida et al. 2001; Calfon et al. 2002). Likewise conserved is the ligation of the cleaved fragments of the mRNA to generate a spliced version encoding a transcription factor (XBP-1 in metazoans) that activates target genes of the UPR (Yoshida et al. 2001; Calfon et al. 2002; Lee et al. 2005). Despite conservation between yeasts and animals of both the biochemistry of IRE1 action and its biological consequences, the ligase mediating $X b p-1$ mRNA splicing in animals remains unknown.

Study of a related process, the ligation of spliced pretRNA halves, has suggested the presence of two alternative enzymatic pathways for attaining this goal in animal cells. The first, homologous to the yeast pathway, uses the $\gamma$-phosphate of ATP to form the phosphodiester bond that reunites the RNA fragments and leaves a $2^{\prime}-\mathrm{PO}_{4}{ }^{2-}$ at the $5^{\prime}$-splice junction (Zillmann et al. 1991). A second enzymatic pathway in mammalian cells has no apparent counterpart in yeast. It rejoins the tRNA halves using the original phosphate that was left at the $3^{\prime}$ end of the $5^{\prime}$-tRNA fragment by the endoribonuclease (Standring et al. 1981; Filipowicz and Shatkin 1983; Laski et al. 1983) similar to the pathway used by archaea to splice tRNAs (Zofallova et al. 2000; Salgia et al. 2003). The yeast-like pathway is presumed to require the removal of the $2^{\prime}-\mathrm{PO}_{4}{ }^{2-}$, as the latter's retention in yeast lacking TPT1 interferes with tRNA maturation (Spinelli et al. 1997), whereas the archaeal-like pathway is unlikely to share this requirement.

Mammalian genomes encode a single known functional homolog of yeast Tpt1p (Zillmann et al. 1991; Spinelli et al. 1998) encoded by $\operatorname{Trpt1}$ (Hu et al. 2003). To gain further insight into the role of $2^{\prime}-\mathrm{PO}_{4}{ }^{2-}$ removal in $\mathrm{Xbp}-1$ splicing, we inactivated the Trpt1 gene in mouse. Despite lack of detectable in vitro RNA 2'-phosphotransferase activity in lysates of cells derived from the Trpt1 knockout mice, there was no evidence for a defect in the UPR or in tRNA function. These findings provide new clues to the mechanism of RNA ligation in mammals.

\section{RESULTS AND DISCUSSION}

The Trpt1 gene was disrupted by homologous recombination in ES cells, deleting exons 3, 4, and part of exon 5 that encode amino acids 48-173 (Fig. 1A). The deletion encompasses residues whose counterparts in yeast Tptlp are essential for enzymatic activity (Sawaya et al. 2005; Steiger et al. 2005) and the mutant allele likely functions as a null. The mutation was transmitted through the germline of chimeric mice. Surprisingly, Trpt1-/- descendents were recovered from mating of heterozygous parents at the $\sim 25 \%$ frequency (expected of a nonlethal mutation; Fig. 1B) and the mutant mice appeared healthy and were normally fertile (data not shown).

Immunoprecipitation of TRPT1 from heart lysates, an abundant source of the enzyme ( $\mathrm{Hu}$ et al. 2003), followed by immunoblot with an antiserum raised to bacterially
A

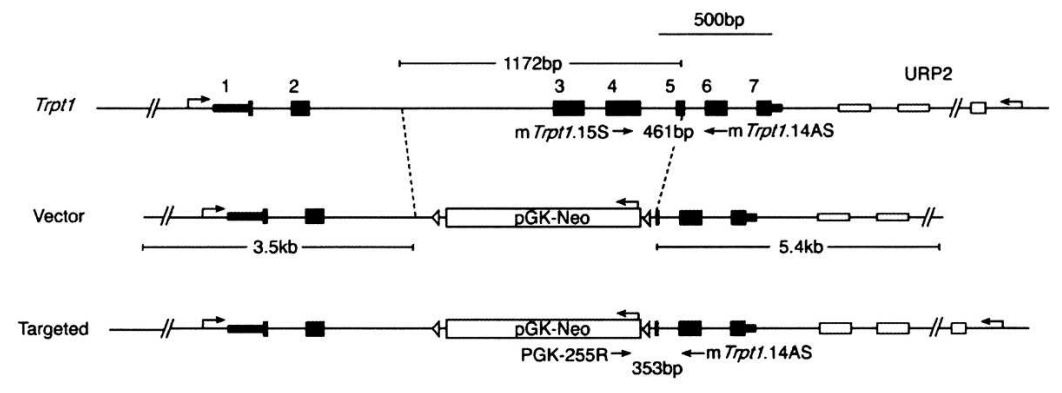

B

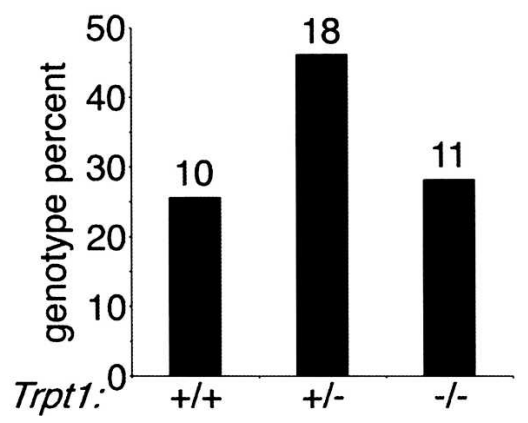

FIGURE 1. Trpt1-/- mice are viable. (A) Schema of the mouse Trpt1 genomic locus, the targeting vector used to disrupt the gene and the structure of the Trpt1-/- mutant allele. The floxed pGK-Neo cassette was inserted in a direction opposite to that of Trpt1 replacing exons 3 , 4, and part of 5. Primers used for genotyping wild-type and Trpt1 mutant alleles are indicated by arrows. (B) Graph of the percent of each genotype obtained in matings of Trpt1+/mice. $\mathrm{N}=39$. (C) Immunoblot of proteins immunopurified with anti-TRPT1 antiserum from extracts of heart tissue from Trpt1 $+/+,+/-$, or $-/-$ mice. The loading control represents a nonspecific protein that copurifies with the TRPT1 antibody. 
expressed murine TRPT1 revealed that $\operatorname{Trpt} 1-/-$ mice lack detectable protein and heterozygotes express $\sim 50 \%$ of wild-type levels (Fig. 1C). These results indicate that unlike its yeast homolog, an essential enzyme (Culver et al. 1997), Trpt1 is dispensable for survival of mammalian cells under normal circumstances.

Trpt1 is the only source of detectable 2 '-phosphotransferase activity in mouse cells validated radiolabeled $\mathrm{U}_{5} \mathrm{P}$ as a substrate for Tpt1p/TRPT1's $2^{\prime}$-phosphotransferease activity in this simple assay.

Extracts of Trpt1+/+ cells had measurable NAD ${ }^{+}$-dependent $2^{\prime}$-phosphotransferase activity, reflected in conversion of the faster migrating $\mathrm{U}_{5} \mathrm{P}$ probe to the slower migrating $\mathrm{U}_{5}$ species (Fig. $2 \mathrm{~B}$, lanes 9,13 ), whereas lysate of $\operatorname{Trpt} 1-/-$ cells lacked detectable 2 ' -phosphotransferase activity (Fig. $2 \mathrm{~B}$, lanes 7,11$)$. The faster migrating species generated in some reactions (Fig. 2B, marked with an asterisks) likely represents cleavage of the probe by a contaminating

To determine if dispensability of Trpt1 reflects dispensability of $2^{\prime}$-phosphotransferase activity, we sought to compare this enzymatic activity in lysates of wild-type cells and Trpt1-/- cells using a modification of an established assay in which it was shown that partially purified HeLa $2^{\prime}$-phosphotransferase specifically removes $2^{\prime}$-phosphates from both ligated tRNAs and RNA substrates as small as di-nucleotides (Zillmann et al. 1992). Mouse embryo fibroblasts were procured from wild-type and Trpt1-/embryos, and immunoblotting confirmed the absence of TRPT1 protein in the latter (Fig. 2A). Two homouridylic pentamer substrates without $\left(\mathrm{U}_{5}\right)$ or with a $2^{\prime}-\mathrm{PO}_{4}{ }^{2-}\left(\mathrm{U}_{5} \mathrm{P}\right)$ at nucleotide position 3 were synthesized and $5^{\prime}$-end labeled with polynucleotide kinase and $\left[\gamma^{32} \mathrm{P}\right]$ ATP. Consistent with the two negative charges provided by the $2^{\prime}-\mathrm{PO}_{4}{ }^{2-}, \mathrm{U}_{5} \mathrm{P}$ had greater mobility than $\mathrm{U}_{5}$ in denaturing PAGE due to a smaller mass charge ratio $(\mathrm{m} / z$ ) (Fig. $2 \mathrm{~B}$, cf. lanes 2 and 5). This provided a criterion for distinguishing RNA molecules that have or lack a $2^{\prime}-\mathrm{PO}_{4}{ }^{2-}$.

Incubation with pure, bacterially expressed yeast Tpt1p (yTpt1p) converted the faster migrating, $\mathrm{U}_{5} \mathrm{P}$ to a species of slower mobility, which comigrated with the $\mathrm{U}_{5}$ reference probe (that lacks a $2^{\prime}$ $\mathrm{PO}_{4}{ }^{2-}$ ) (Fig. 2B, lanes 4,5). This conversion was dependent on addition of $\mathrm{NAD}^{+}$to the reaction, and is consistent with the known dependence of Tptlp's $2^{\prime}$-phosphotransferease activity on $\mathrm{NAD}^{+}$ as a cosubstrate. Appr $>\mathrm{p}$ and nicotinamide (products predicted by the reaction) remain undetected, as they are unlabeled and yTptlp had no effect on the mobility of the $\mathrm{U}_{5}$ probe, as predicted (Fig. 2B, lane 1). These observations

A.

B

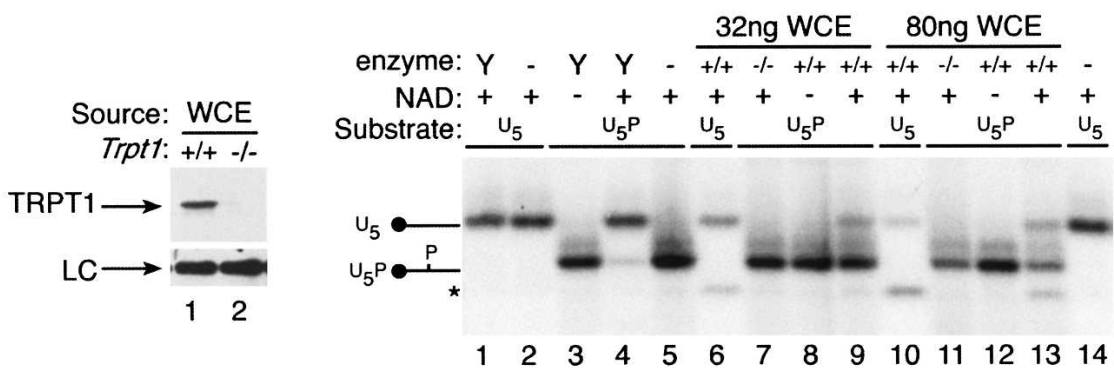

C.

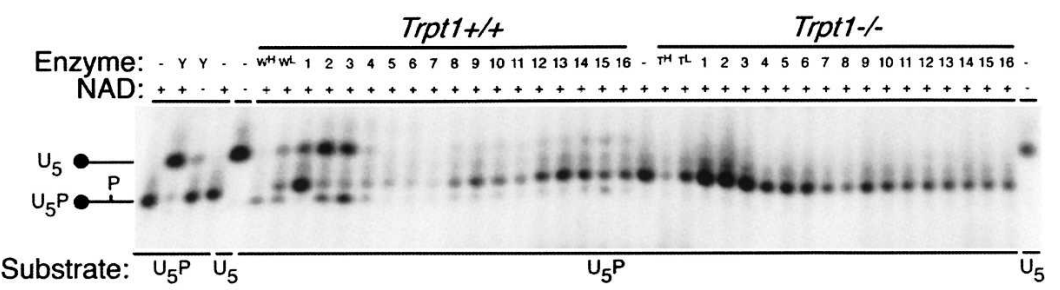

D

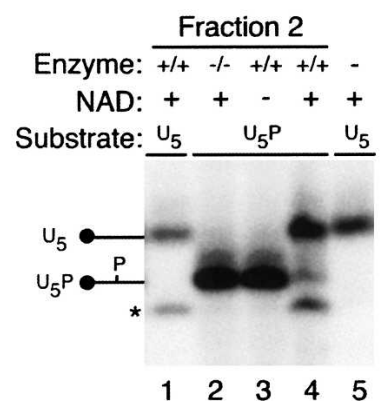

FIGURE 2. Trpt1-/- cell extracts lack $2^{\prime}$-phosphotransferase activity. (A) Anti-TRPT1 immunoblot of proteins immunopurified from Trpt1+/+ or Trpt1-/- cells. (B) Autoradiograph of $5^{\prime}-{ }^{32} \mathrm{PO}_{4}{ }^{2-}$-labeled RNA substrates consisting of five uridines $\left(\mathrm{U}_{5}\right)$ or five uridines with a $2^{\prime}-\mathrm{PO}_{4}{ }^{2-}$ on the third base $\left(\mathrm{U}_{5} \mathrm{P}\right)$ that have been incubated in the absence $(-)$ or presence of purified yeast Tptlp $(Y)$ or $32 \mathrm{ng}$ or $80 \mathrm{ng}$ protein from whole cell extracts (WCE) from $\operatorname{Trpt+/+}(W)$ or Trpt1-/- $(T)$ cells with or without $\mathrm{NAD}^{+}$. Migration of the radiolabeled $\mathrm{U}_{5}$ and $\mathrm{U}_{5} \mathrm{P}$ probes and that of a degradation product $\left(^{*}\right)$ is marked to the left of the autoradiogram. $(C)$ Autoradiograph of 2 -phosphotransferase reaction products from substrates incubated with yTptlp (Y); WCE from Trpt+/+ or Trpt1-/- $\left(80 \mathrm{ng}\left[\mathrm{W}^{\mathrm{L}}, \mathrm{T}^{\mathrm{L}}\right]\right.$ or $160 \mathrm{ng}$ $\left.\left[\mathrm{W}^{\mathrm{H}}, \mathrm{T}^{\mathrm{H}}\right]\right)$, or $5 \mu \mathrm{L}$ of the indicated fraction of proteins separated on a $10 \%-30 \%$ glycerol gradient. $(D)$ Evaluation of the $\mathrm{NAD}^{+}$dependence of the $2^{\prime}$-phosphotransferase activity from the peak (fraction 2) of the glycerol gradients shown in panel $C$. 
nuclease. Appearance of this fast-migrating species upon incubation of the $\mathrm{U}_{5}$ probe with cell lysate (Fig. 2B, lanes $6,10)$ and its absence from samples in which the $\mathrm{U}_{5} \mathrm{P}$ probe was incubated with lysate but without $\mathrm{NAD}^{+}$(Fig. $2 \mathrm{~B}$, lanes 8,12 ) argues that a $2^{\prime}-\mathrm{PO}_{4}{ }^{2-}$ protects the RNA probe from degradation and suggests that the contaminating nuclease is a conventional RNase (Zillmann et al. 1991).

To confirm these observations we fractionated proteins from wild-type and Trpt1-/- cells on glycerol gradients and measured $2^{\prime}$-phosphotransferase activity in the various fractions. Lysates from wild-type cells had a conspicuous peak of $\mathrm{NAD}^{+}$-dependent 2 -phosphotransferase activity in light fractions (Fig. 2C, fractions 1-3, 2D, lane 4) that was absent from samples prepared from mutant cells. Much weaker activity was present in heavier fractions (Fig. 2C, fractions 8-16), and variable levels of contaminating RNase activity were also noted (Fig. 2C, fractions 4-7). No activity was detected in fractions from Trpt1-/- lysates. Our observations are consistent with a previous report demonstrating a single peak of $2^{\prime}$-phosphotransferase activity in fractionated HeLa extracts (Zillmann et al. 1992) and indicate that $\operatorname{Trpt1} 1-/-$ cells lack an alternative 2 '-phosphotransferase detectable by this assay.

\section{Normal translation of spliced XBP-1 mRNA in ER stressed Trpt1-/- cells}

Were it to occur by a yeast-like pathway, ligation of IRE1cleaved XBP-1 mRNA is predicted to result in (normally transient) $2^{\prime}$ phosphorylation of the splice junction guanosine 832. In Trpt1-/- cells the spliced XBP-1 mRNA is predicted to retain this $2^{\prime}-\mathrm{PO}_{4}{ }^{2-}$ on guanosine 832 , which is the first codon for alanine 161. High-resolution structure of the translating small ribosomal subunit reveals hydrogen bonding between the $2^{\prime} \mathrm{OH}$ of the universally conserved base (A1492 of the $16 \mathrm{~S}$ ribosomal RNA) and the $2^{\prime} \mathrm{OH}$ of the first codon on the mRNA, as the latter base pairs with the cognate tRNA in the ribosome's " $\mathrm{A}$ " site (Ogle et al. 2001). Barring an unanticipated major functional difference between mammalian and bacterial ribosomes, the disruption of this conserved contact by a $2^{\prime}-\mathrm{PO}_{4}{ }^{2-}$ on the first codon is predicted to interfere with monitoring codon-anticodon interactions in translation of the $2^{\prime}$-phosphorylated spliced XBP-1 mRNA. Therefore, we examined the consequences of Trpt1 deficiency on XBP-1 expression in ER stressed cultured cells.

The unspliced XBP-1 mRNA encodes a $30-\mathrm{kDa}$ unstable protein $(\mathrm{XBP}-1 \mathrm{u})$ that does not accumulate in cells, whereas the spliced mRNA encodes a $39-\mathrm{kDa}$ protein (XBP-1p) that is detectable by immunoblot as an anomalously migrating $54-\mathrm{kDa}$ species from nuclear extracts of stressed cells (Yoshida et al. 2001; Calfon et al. 2002). Therefore, we compared the level of XBP-1p protein and other ER stress markers in Trp1+/+ and Trpt1-/- cells, following activation of the unfolded protein response by tunicamycin or thapsigargin (drugs that cause protein misfolding in the ER). Trpt1+/+ and Trpt1-/- cells responded similarly and predictably to ER stress, initially with increased eIF $2 \alpha$ phosphorylation that recovers to basal levels following induction of the eIF $2 \alpha$ phosphatase GADD34. Furthermore, cells from both genotypes induced $\mathrm{XBP}-1 \mathrm{p}$ and the ER stress responsive target $\mathrm{CHOP}$ in parallel, with only subtle differences in kinetics (Fig. 3A).

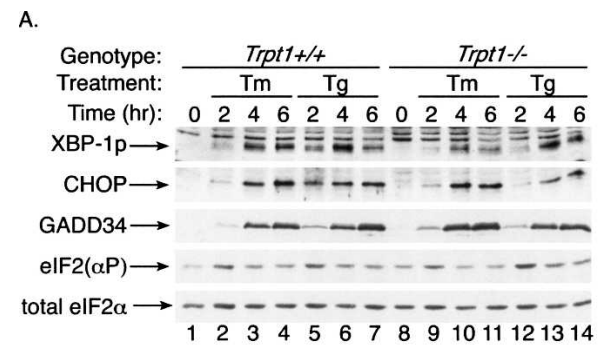

B.

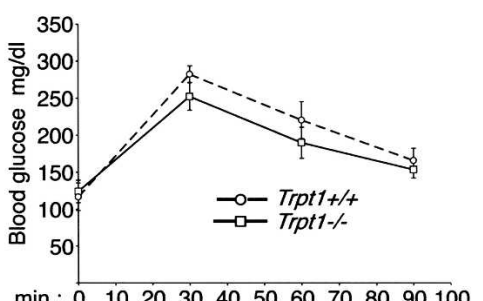

C.
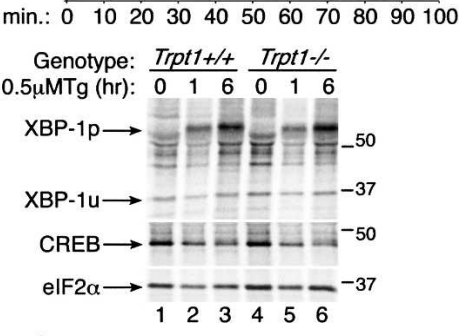

D.

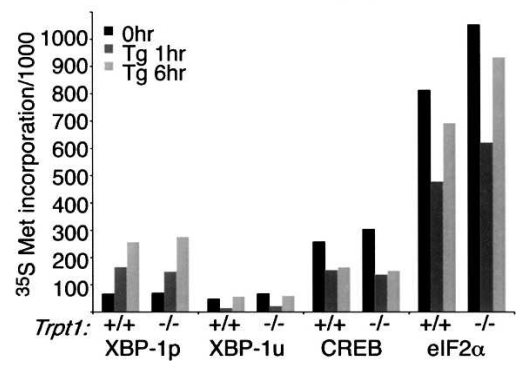

FIGURE 3. XBP-1p is expressed Trpt1-/- cells. (A) Immunoblot detection of XBP-1, CHOP, GADD34, phospho-eIF2 $\alpha$, and total eIF2 $\alpha$ from nuclear (upper two panels) or cytoplasmic (lower three panels) extracts prepared from Trpt1+/+ or Trpt1-/- cells treated with $2 \mu \mathrm{g} / \mathrm{mL}$ tunicamycin $(\mathrm{Tm})$ or $0.5 \mu \mathrm{M}$ thapsigargin $(\mathrm{Tg})$ for the indicated period in order to perturb protein folding in the endoplasmic reticulum and activate the UPR. (B) Blood glucose levels of Trpt1+/+ and Trpt1-/- mice at the indicated time points following intraperitoneal injection of $2 \mathrm{mg} / \mathrm{kg}$ body weight glucose. (C) Autoradiograph of XBP-1p, XBP-1u, CREB, and eIF $2 \alpha$ immunopurified from Trpt1+/+ and Trpt1-/- cells that were treated with thapsigargin for a total of 0,1 , or $6 \mathrm{~h}$ and metabolically labeled for the last hour with ${ }^{35} \mathrm{~S}$-methionine/cysteine in the presence of the proteosome inhibitor MG132. (D) Quantitation of the ${ }^{35} \mathrm{~S}$-methionine/cysteine incorporation into the proteins shown in panel $C$. 
These findings indicate that cells of either genotype experienced similar levels of stress and suggest similar capability to translate the spliced XBP-1p mRNA.

Glucose homeostasis is sensitive to subtle defects in the UPR in general and in XBP-1 function in particular, as hemizygous loss of XBP-1 promotes insulin resistance (Ozcan et al. 2004). However, glucose tolerance, reflected in the ability of mice to assimilate a load of injected glucose, was unimpaired in Trpt1-/- mice (Fig. 3B), further arguing against a severe functional defect in XBP-1 expression in the mutant mice. It is worth noting, however, that a subtler defect in XBP-1 function may have been missed by this assay but may be exposed in the future by placing Trpt1-/- mice on a high-fat diet (Ozcan et al. 2004).

To directly compare synthesis rates of XBP-1p and XBP1u, Trpt1+/+ and Trpt1-/- cells were exposed to thapsigargin in the presence the proteasome inhibitor MG132 (which stabilizes the $\mathrm{XBP}-1 \mathrm{u}$ protein) and the incorporation of ${ }^{35} \mathrm{~S}$-methionine/cysteine into newly synthesized proteins was measured by brief pulse-labeling and immunoprecipitation. Both forms of XBP-1 and the reference proteins, CREB and eIF $2 \alpha$, were synthesized at similar rates in Trpt1+/+ and Trpt1-/- cells (Fig. 3C,D), arguing against significant retention of a $2^{\prime}-\mathrm{PO}_{4}{ }^{2-}$ at the XBP-1p mRNA splice junction.

\section{Normal translation of tyrosine-rich proteins in Trpt1-/- cells}

Retention of the $2^{\prime}-\mathrm{PO}_{4}{ }^{2-}$ in spliced yeast tRNAs compromises an essential modification of the normally hypermodified position one base $3^{\prime}$ of the anticodon (Spinelli et al. 1997). Since all known functional tRNA ${ }^{\mathrm{Tyr}}$ genes in mice (and humans) contain introns disrupting their anticodon loops (Lowe and Eddy 1997), the tRNA ${ }^{\mathrm{Tyr}}$ pool is predicted to be sensitive to defects in tRNA splicing, were they to occur. The relative incorporation of tyrosine into newly synthesized proteins was therefore used as a surrogate for the functional state of the tRNA ${ }^{\mathrm{Tyr}}$ pools in Trpt1+/+ and Trpt1-/- cells.

Whether grown in serum-poor media (which represses translation) or serum-rich media (which stimulates it), Trpt+/+ and Trpt1-/- cells incorporated ${ }^{35}$ S-methionine/ cysteine indistinguishably into the tyrosine-rich proteins EWS, TLS/FUS, and TAF15 (tyrosine content $6.4 \%, 6.9 \%$, and $9 \%$, respectively), eIF2 $\alpha$ (a protein with average tyrosine content, 3.8\%) and total cellular proteins (Fig. $4 \mathrm{~A}$, cf. lanes 1,6 and 3,8,4B, quantified). Comparison of incorporation of ${ }^{3} \mathrm{H}$-tyrosine and ${ }^{35} \mathrm{~S}$-methionine/cysteine into total proteins confirmed that wild-type and Trpt1-/cells had similar incorporation rates of either amino acid (Fig. 4C). Together these findings argue against the defect in the function of spliced tRNA ${ }^{\text {Tyr }}$ that is predicted by the retention of a $2^{\prime}-\mathrm{PO}_{4}{ }^{2-}$ at the splice junction, were it to occur in mutant cells, although it remains formally possible

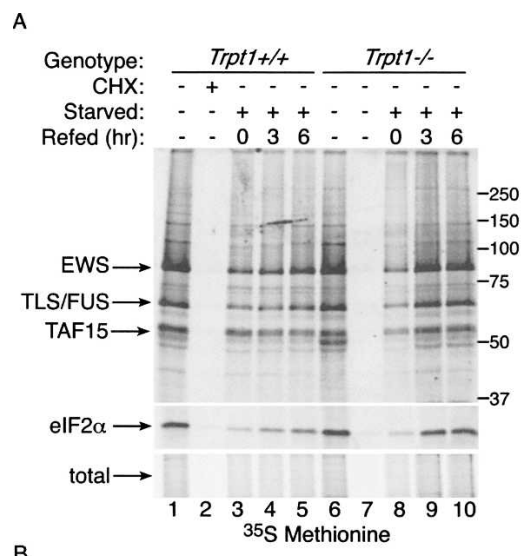

B

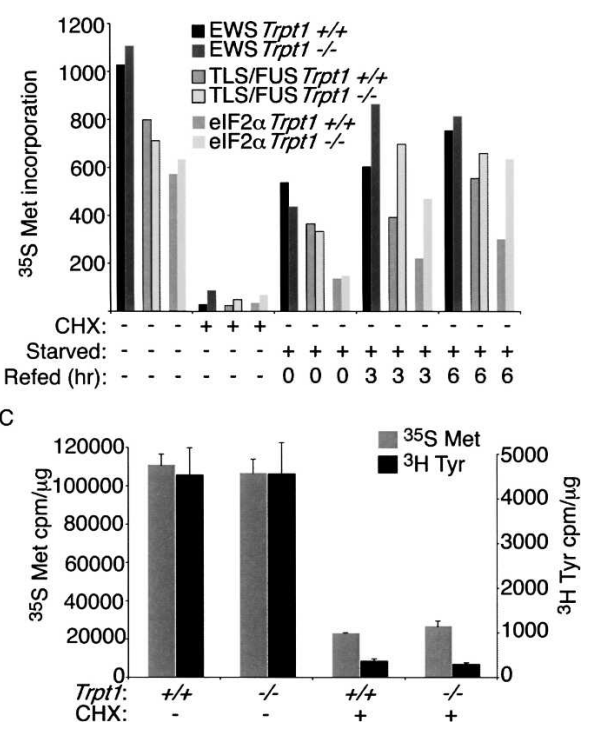

FIGURE 4. Trpt1-/- cells incorporate tyrosine into proteins at normal rates. $(A)$ Autoradiograph of ${ }^{35} \mathrm{~S}$-methionine/cysteine metabolically labeled immunopurified tyrosine-rich proteins TLS/FUS (6.9\% tyrosine), EWS (6.41\% tyrosine), and TAF15 (9\% tyrosine), eIF $2 \alpha(3.8 \%$ tyrosine, representing a protein of average tyrosine content) (Echols et al. 2002) from $\operatorname{Trp} t+/+$ and $\operatorname{Trpt} 1-/-$ cells that were either untreated, treated with $100 \mu \mathrm{g} / \mathrm{mL}$ cycloheximide for $5 \mathrm{~min}$ before and during labeling, or serum starved for $48 \mathrm{~h}$ followed by continued starvation or refeeding for the indicated time prior to labeling for $1 \mathrm{~h}$ prior to harvest ( $54 \mathrm{~h}$ total). The bottom panel displays ${ }^{35} \mathrm{~S}$-methionine/cysteine incorporation into total protein from each sample. $(B)$ Quantitation of the radiolabel incorporated into EWS, TLS, and eIF $2 \alpha$ (from $A$ ). Quantitation of ${ }^{3} \mathrm{H}$-tyrosine and ${ }^{35}$ S-methionine/cysteine incorporation into TCA precipitable proteins in Trpt $1+/+$ and Trpt1-/- cells. Mean \pm SEM for triplicate samples is shown.

that both the tRNA charging (tRNA ${ }^{\text {tyr }}$ ) synthetase and the mammalian ribosome have evolved to function in presence of a $2^{\prime}-\mathrm{PO}_{4}{ }^{2-}$ in the anticodon loop of tRNAs.

\section{CONCLUSIONS}

Trpt1-/- cells lack detectable in vitro RNA $2{ }^{\prime}$-phosphotransferase activity yet retain the ability to translate spliced 
XBP-1 mRNA and synthesize tyrosine-containing proteins at wild-type levels. Barring the existence of an enzymatic activity that is undetected by our assay, these findings point directly to the dispensability of $2^{\prime}$-phosphotransferase activity in mice and provide a strong indirect argument against the presence of a $2^{\prime}-\mathrm{PO}_{4}{ }^{2-}$ at the splice junction of ligated XBP- $1 \mathrm{p}$ and $\mathrm{tRNA}^{\mathrm{tyr}}$ RNA molecules in animals. Given that a $2^{\prime}-\mathrm{PO}_{4}{ }^{2-}$ at the splice junction is a feature of the yeast-like ligation pathway, the findings presented here are consistent with that pathway's dispensability in mammals and suggests the sufficiency of the archaea like pathway. This conclusion is further supported by the viability of mouse cells lacking CNP1 (Lappe-Siefke et al. 2003), the only mammalian enzyme known to perform the first step in the yeast-like ligation pathway (hydrolysis of the $2^{\prime}-3^{\prime}$-cyclic phosphate bond at the $5^{\prime}$-splice site (Schwer et al. 2007).

The preeminence in mammals of the biochemically defined archaea-like pathway for RNA end joining that is suggested by this study is seemingly challenged by the finding that inactivation of hClp1, a mammalian kinase that phosphorylates the $5^{\prime}-\mathrm{OH}$ of RNA fragments, reduces the in vitro tRNA splicing activity of cell lysates (Weitzer and Martinez 2007). An analysis of hClpl's role in RNA ligation in vivo might be informative; however, the interpretation of this data would be challenging because hClp1 has other functions such as promoting mRNA 3 '-end formation (Paushkin et al. 2004). Thus, clarity of the pathways contributing to end joining awaits identification and mutational analysis of the elusive enzyme(s) catalyzing the reaction in mammals.

Our phenotypic analysis of the Trpt1-/- mice had focused on the essential aspects of expression of spliced XBP-1 mRNA and surrogate measures of tRNA processing, which appear unaffected by the mutation. However, more subtle defects in these or other processes could easily have been missed. For example, it might be important to determine if the Trpt1-/- mice phenocopy the Cnp1-/mice and also develop a late-onset neurodegenerative disorder (Lappe-Siefke et al. 2003). Given that the two enzymes likely work sequentially in a linear pathway, it might then be worth inquiring into the possibility of a hitherto undiscovered signaling role for their product, Appr $>$ p. These questions are of more than academic interest: TPT1 and the yeast-like pathway for RNA ligation are essential in yeast. If, as our study and the accompanying paper (Schwer et al. 2007) suggest, they might be dispensable to mammalian health, inhibitors of Tptlp (and possibly Trllp) might prove useful as selective antifungal agents.

\section{MATERIALS AND METHODS}

\section{Gene targeting and animal experiments}

The murine Trpt1 gene was targeted in E14 ES cells with a positive-negative selection vector in which a floxed $P G K:: n e o^{r}$ cassette oriented opposed to transcription of the Trpt1 gene was used to replace a 1172 bp genomic region encompassing exons 3,4 , and part of exon 5 that encode amino acids 48-173. The 5 '-homology arm consists of the 3,478bp Ssp1 and XbaI fragment of the 4253-bp PCR product amplified from ES cell genomic DNA using primers mTPT1.9S: 5' -TACCTGTCAGGCTGACTTCT CAGTAGCCTGG-3' ${ }^{\prime}$ and mTPT1.8AS: $5^{\prime}$-TGCTTTTCGTTGGTA TTGACCACGAGCTGCAC-3'. The 3'-homology arm consists of the 5409-bp ClaI and XbaI fragment of the 6176-bp PCR product amplified from ES cell genomic DNA using primers mTPT.13S: 5'-AGTCCATGGTACATTCTGGAAGCACTGGCCATC-3' and mTPT.6AS: 5'-GGATCACACTAGGCTCAGTTTCATGCAAC ACTG-3'.

Clones from two individually selected heterozygous ES cell lines were injected into blastocysts and the resultant founder chimeras bred to obtain two lines of $\operatorname{Trpt1+/}-$ and $\operatorname{Trpt1} 1-/-$ mice that were both viable and healthy. Line 1D1 was used in subsequent studies to obtain tissue and mouse embryonic fibroblasts (MEF). For the glucose tolerance test, mice were fasted overnight $(14 \mathrm{~h})$ and injected intraperitoneally with a glucose solution $(2 \mathrm{mg} / \mathrm{kg})$. All experiments in mice were approved by the NYU Institutional Animal Care and Use Committee.

\section{Cell culture}

Trpt1+/+ and Trpt1-/- cell lines were obtained by serial passage of SV40-T-antigen transfected MEFs. The cells were cultured in DMEM supplemented with 10\% Fetal Clone II serum (Hyclone), and penicillin-streptomycin and glutamine. Extracts were made from PBS-washed cells collected by scraping and centrifugation ( $500 \mathrm{~g}$ for $5 \mathrm{~min}$ ) and passage through a ball-bearing homogenizer (EMBL) after resuspension in four volumes of extract buffer $(20 \mathrm{mM}$ Tris- $\mathrm{HCl}$ at $\mathrm{pH} 7.5,300 \mathrm{mM} \mathrm{KCl}, 10 \mathrm{mM} \mathrm{MgCl}_{2}, 1 \mathrm{mM} \mathrm{DTT}$, $1 \mu \mathrm{g} / \mathrm{mL}$ pepstatin and aprotinin, and $1 \mathrm{mM}$ PMSF) followed by clearing at 14,000 rpm. For Figure 2B, $2.7 \mathrm{mg}$ of lysate from cells of each genotype was separated on a $5-\mathrm{mL} 10 \%-30 \%$ glycerol gradient made in extract buffer followed by centrifugation at $40,000 \mathrm{rpm}$ for $12 \mathrm{~h}$ in a SW50 rotor.

\section{Substrates and TRPT1 assay}

The uridylic acid pentamer $\left(\mathrm{rU}_{5}\right)$ was synthesized using standard 2 '-TBDMS phosphoramidite chemistry (Usman et al. 1987). The $\mathrm{rU}$ pentamer containing the internal $2^{\prime}-\mathrm{PO}_{4}{ }^{2-}$ moiety was synthesized by the same method except that the monomer $5^{\prime}-O-$ (levulinyl)-2'-O-(4,4' -dimethoxytrityl)uridine $3^{\prime}$-O-(2-cyanoethyl$\mathrm{N}, \mathrm{N}$-diisopropyl) phosphoramidite was introduced at position 3 . Following assembly of the trinucleotide, the cyanoethyl groups were removed with 2:3 triethylamine/acetonitrile followed by removal of the $2^{\prime}$-DMT group with $3 \%$ trichloroacetic acid. The free $2^{\prime}-\mathrm{OH}$ group was phosphitylated using bis(2-cyanoethyl)-(N,N-diisopropyl)-phosphoramidite and then oxidized with $\mathrm{I}_{2}$ /water to complete the incorporation of the 2 '-phosphate moiety. The growing oligonucleotide was then subjected to a $\mathrm{Ac}_{2} \mathrm{O}$ to cap any unreacted 2 '-OH. The 5 '-levulinyl group was removed using hydrazyne hydrate (Lackey et al. 2007) and oligonucleotide synthesis continued by coupling 2'-TBDMS rU 3 '-amidite monomers. Cleavage of the pentamer from the support, deprotection, and purification (PAGE) was carried out 
as described by literature procedures (Damha and Ogilvie 1993). The pentamers were characterized by electron spray (ESI) mass spectrometry.

The $2^{\prime}$-phosphotransferase assay reaction mixes contained $0.2 \mathrm{pm} / \mu \mathrm{L} 5^{\prime}{ }^{32} \mathrm{P}$-end labeled ribo-oligonucleotide in $20 \mathrm{mM}$ Tris- $\mathrm{HCl}$ at $\mathrm{pH} 7.5,5 \mathrm{mM} \mathrm{MgCl}, 2.5 \mathrm{mM}$ spermidine, $0.4 \%$ Triton $\mathrm{X}-100,100 \mu \mathrm{M} \mathrm{DTT}$, and $1 \mathrm{mM} \mathrm{NAD}^{+}, 1 \mu \mathrm{g}$ of purified bacterially expressed yTptlp, or the indicated preparation of cell extract. The $20-\mu \mathrm{L}$ reactions were incubated at $30^{\circ} \mathrm{C}$ for $30 \mathrm{~min}$, followed by phenol-chloroform extraction, precipitation, and separation of the products on $6 \mathrm{M}$ Urea-25\% Acrylamide-TBE gels.

\section{Protein analysis}

Trpt1 was detected in heart or MEF cell lysates by immunoprecipitation, followed by immunoblotting using previously described buffers (Harding et al. 2001b) and a polyclonal rabbit antiserum raised against bacterially expressed and purified mouse TRPT1 (a kind gift of the Phizicky laboratory). Procedures and antisera for detecting XBP-1p, CHOP, GADD34, and eIF2 by direct immunoblotting of nuclear and cytoplasmic lysates have been previously described (Harding et al. 2001a; Novoa et al. 2001; Calfon et al. 2002). Phosphorylated eIF2 $\alpha$ was detected using the BioSource antibody \#44-728G lot \#0702.

The translation of XBP-1u, XBP1p, CREB, TLS/FUS, EWS, TAF15, and eIF2 $\alpha$ was measured by pulse-labeling and immunoprecipitation in Trpt1+/+ and Trpt1-/- MEF cell lines. For $\left[{ }^{35} \mathrm{~S}\right]$ methionine/cysteine metabolic labeling for immunoprecipitation, cells were switched to methionine and cysteine minus DMEM with $10 \%$ dialyzed fetal calf serum 5 min before addition of -TRAN ${ }^{35}$ S-LABEL (MP Biomedical) at $400 \mu \mathrm{Ci} / \mathrm{mL}$ for $60 \mathrm{~min}$. MG132 $(10 \mu \mathrm{M})$ was added 5 min before TRAN ${ }^{35}$ S-LABEL where indicated. For measurement of $\left[{ }^{35} \mathrm{~S}\right]$ methionine/cysteine or ${ }^{3} \mathrm{H}$ tyrosine incorporation into total proteins (Fig. 4C), cells were washed in Hanks buffer supplemented with $10 \%$ dialyzed fetal calf serum and $10 \mathrm{mM}$ glucose and then labeled in the same medium supplemented with $5.5 \mu \mathrm{Ci} / \mathrm{mL}$ TRAN ${ }^{35} \mathrm{~S}$-LABEL or ${ }^{3} \mathrm{H}$-tyrosine (MP Biomedical) for $2 \mathrm{~h}$. Cells were lysed in RIPA, cleared, and the incorporation of each label into TCA precipitable protein was measured by scintillation counting.

\section{Statistical analysis}

All results are expressed as mean \pm SEM.

\section{ACKNOWLEDGMENTS}

We thank Eric Phizicky (University of Rochester) for purified bacterially expressed TRPT1 protein used for antibody production and for advice, dispensed over many years; Susan Hsiao for characterization of the anti-TRPT1 antibody; Jim Delaney (MIT) and Sarah Woodson (Johns Hopkins) for advice; the New York University transgenic facility for production of Trpt1 mutant chimeric mice; and Miho Oyadomari for help in breeding and genotyping them. This work was supported by NIH Grants DK47119 and ES08681 (D.R.) and an NSERC Discovery grant (M.J.D.).

Received October 2, 2007; accepted November 8, 2007.

\section{REFERENCES}

Abelson, J., Trotta, C.R., and Li, H. 1998. tRNA splicing. J. Biol. Chem. 273: $12685-12688$.

Calfon, M., Zeng, H., Urano, F., Till, J.H., Hubbard, S.R., Harding, H.P., Clark, S.G., and Ron, D. 2002. IRE1 couples endoplasmic reticulum load to secretory capacity by processing the XBP-1 mRNA. Nature 415: 92-96.

Cox, J.S. and Walter, P. 1996. A novel mechanism for regulating activity of a transcription factor that controls the unfolded protein response. Cell 87: 391-404.

Culver, G.M., McCraith, S.M., Zillmann, M., Kierzek, R., Michaud, N., LaReau, R.D., Turner, D.H., and Phizicky, E.M. 1993. An NAD derivative produced during transfer RNA splicing: ADP-ribose 1"-2" cyclic phosphate. Science 261: 206-208.

Culver, G.M., McCraith, S.M., Consaul, S.A., Stanford, D.R., and Phizicky, E.M. 1997. A 2'-phosphotransferase implicated in tRNA splicing is essential in Saccharomyces cerevisiae. J. Biol. Chem. 272: 13203-13210.

Damha, M.J. and Ogilvie, K.K. 1993. Oligoribonucleotide synthesis. The silyl-phosphoramidite method. Methods Mol. Biol. 20: 81-114.

Echols, N., Harrison, P., Balasubramanian, S., Luscombe, N.M., Bertone, P., Zhang, Z., and Gerstein, M. 2002. Comprehensive analysis of amino acid and nucleotide composition in eukaryotic genomes, comparing genes and pseudogenes. Nucleic Acids Res. 30: 2515-2523. doi: 10.1093/nar/30.11.2515.

Filipowicz, W. and Shatkin, A.J. 1983. Origin of splice junction phosphate in tRNAs processed by HeLa cell extract. Cell 32: 547557.

Gonzalez, T.N., Sidrauski, C., Dorfler, S., and Walter, P. 1999. Mechanism of non-spliceosomal mRNA splicing in the unfolded protein response pathway. EMBO J. 18: 3119-3132.

Harding, H., Zeng, H., Zhang, Y., Jungreis, R., Chung, P., Plesken, H., Sabatini, D., and Ron, D. 2001a. Diabetes mellitus and exocrine pancreatic dysfunction in Perk-/- mice reveals a role for translational control in survival of secretory cells. Mol. Cell 7: 11531163.

Harding, H.P., Novoa, I., Bertolotti, A., Zeng, H., Zhang, A., Urano, F., Jousse, C., and Ron, D. 2001b. Translational regulation in the cellular response to biosynthetic load on the endoplasmic reticulum. Cold Spring Harb. Symp. Quant. Biol. 66: 499-508.

Hopper, A.K. and Phizicky, E.M. 2003. tRNA transfers to the limelight. Genes \& Dev. 17: 162-180.

Hu, Q.D., Lu, H., Huo, K., Ying, K., Li, J., Xie, Y., Mao, Y., and Li, Y.Y. 2003. A human homolog of the yeast gene encoding tRNA 2 '-phosphotransferase: Cloning, characterization and complementation analysis. Cell. Mol. Life Sci. 60: 1725-1732.

Lackey, J.G., Sabatino, D., and Damha, M.J. 2007. Solid-phase synthesis and on-column deprotection of RNA from 2'- (and $3^{\prime}$-) O-levulinated (Lv) ribonucleoside monomers. Org. Lett. 9: 789-792.

Lappe-Siefke, C., Goebbels, S., Gravel, M., Nicksch, E., Lee, J., Braun, P.E., Griffiths, I.R., and Nave, K.A. 2003. Disruption of Cnp1 uncouples oligodendroglial functions in axonal support and myelination. Nat. Genet. 33: 366-374.

Laski, F.A., Fire, A.Z., Rajbhandary, U.L., and Sharp, P.A. 1983. Characterization of tRNA precursor splicing in mammalian extracts. J. Biol. Chem. 258: 11974-11980.

Lee, A.H., Chu, G.C., Iwakoshi, N.N., and Glimcher, L.H. 2005. XBP1 is required for biogenesis of cellular secretory machinery of exocrine glands. EMBO J. 24: 4368-4380.

Lowe, T.M. and Eddy, S.R. 1997. tRNAscan-SE: A program for improved detection of transfer RNA genes in genomic sequence. Nucleic Acids Res. 25: 955-964. doi: 10.1093/nar/25.5.955.

Mori, K., Kawahara, T., Yoshida, H., Yanagi, H., and Yura, T. 1996. Signalling from endoplasmic reticulum to nucleus: Transcription factor with a basic-leucine zipper motif is required for the unfolded protein-response pathway. Genes Cells 1: 803-817. 
Novoa, I., Zeng, H., Harding, H., and Ron, D. 2001. Feedback inhibition of the unfolded protein response by GADD34-mediated dephosphorylation of eIF2 $\alpha$. J. Cell Biol. 153: 1011-1022.

Ogle, J.M., Brodersen, D.E., Clemons Jr., W.M., Tarry, M.J., Carter, A.P., and Ramakrishnan, V. 2001. Recognition of cognate transfer RNA by the 30S ribosomal subunit. Science 292: 897-902.

Ozcan, U., Cao, Q., Yilmaz, E., Lee, A.H., Iwakoshi, N.N., Ozdelen, E., Tuncman, G., Gorgun, C., Glimcher, L.H., and Hotamisligil, G.S. 2004. Endoplasmic reticulum stress links obesity, insulin action, and type 2 diabetes. Science 306: 457-461.

Paushkin, S.V., Patel, M., Furia, B.S., Peltz, S.W., and Trotta, C.R. 2004. Identification of a human endonuclease complex reveals a link between tRNA splicing and pre-mRNA $3^{\prime}$ end formation. Cell 117: 311-321.

Ron, D. and Walter, P. 2007. Signal integration in the endoplasmic reticulum unfolded protein response. Nat. Rev. Mol. Cell Biol. 8: 519-529.

Ruegsegger, U., Leber, J.H., and Walter, P. 2001. Block of HAC1 mRNA translation by long-range base-pairing is released by cytoplasmic splicing upon induction of the unfolded protein response. Cell 107: 103-114.

Salgia, S.R., Singh, S.K., Gurha, P., and Gupta, R. 2003. Two reactions of Haloferax volcanii RNA splicing enzymes: Joining of exons and circularization of introns. RNA 9: 319-330.

Sawaya, R., Schwer, B., and Shuman, S. 2005. Structure-function analysis of the yeast $\mathrm{NAD}^{+}$-dependent tRNA $2^{\prime}$-phosphotransferase Tpt1. RNA 11: 107-113.

Schwer, B., Aronova, A., Ramirez, A., Braun, P., and Shuman, S. 2007. Mammalian 2', 3' cyclic nucleotide phosphodiesterase (CNP) can function as a tRNA splicing enzyme in vivo. RNA (this issue). doi: $10.1261 /$ rna.858108.

Schwer, B., Sawaya, R., Ho, C.K., and Shuman, S. 2004. Portability and fidelity of RNA-repair systems. Proc. Natl. Acad. Sci. 101: 2788-2793.

Sidrauski, C., Cox, J.S., and Walter, P. 1996. tRNA ligase is required for regulated mRNA splicing in the unfolded protein response. Cell 87: 405-413.

Spinelli, S.L., Consaul, S.A., and Phizicky, E.M. 1997. A conditional lethal yeast phosphotransferase (tptl) mutant accumulates tRNAs with a $2^{\prime}$-phosphate and an undermodified base at the splice junction. RNA 3: 1388-1400.
Spinelli, S.L., Malik, H.S., Consaul, S.A., and Phizicky, E.M. 1998. A functional homolog of a yeast tRNA splicing enzyme is conserved in higher eukaryotes and in Escherichia coli. Proc. Natl. Acad. Sci. 95: 14136-14141.

Standring, D.N., Venegas, A., and Rutter, W.J. 1981. Yeast tRNA3Leu gene transcribed and spliced in a HeLa cell extract. Proc. Natl. Acad. Sci. 78: 5963-5967.

Steiger, M.A., Jackman, J.E., and Phizicky, E.M. 2005. Analysis of 2'-phosphotransferase (Tptlp) from Saccharomyces cerevisiae: Evidence for a conserved two-step reaction mechanism. RNA 11: 99-106.

Tirasophon, W., Welihinda, A.A., and Kaufman, R.J. 1998. A stress response pathway from the endoplasmic reticulum to the nucleus requires a novel bifunctional protein kinase/endoribonuclease (Irelp) in mammalian cells. Genes \& Dev. 12: 1812-1824.

Usman, N., Ogilvie, K.K., Jiang, M.Y., and Cedergren, R.J. 1987. The automated chemical synthesis of long oligoribuncleotides using 2'-O-silylated ribonucleoside 3 '-O-phosphoramidites on a controlled-pore glass support: Synthesis of a 43-nucleotide sequence similar to the $3^{\prime}$-half molecule of an Escherichia coli formylmethionine tRNA. J. Am. Chem. Soc. 109: 7845-7854.

Wang, X.Z., Harding, H.P., Zhang, Y., Jolicoeur, E.M., Kuroda, M., and Ron, D. 1998. Cloning of mammalian Irel reveals diversity in the ER stress responses. EMBO J. 17: 5708-5717.

Weitzer, S. and Martinez, J. 2007. The human RNA kinase hClp1 is active on $3^{\prime}$ transfer RNA exons and short interfering RNAs. Nature 447: 222-226.

Yoshida, H., Matsui, T., Yamamoto, A., Okada, T., and Mori, K. 2001. XBP1 mRNA is induced by ATF6 and spliced by IRE1 in response to ER stress to produce a highly active transcription factor. Cell 107: 881-891.

Zillmann, M., Gorovsky, M.A., and Phizicky, E.M. 1991. Conserved mechanism of tRNA splicing in eukaryotes. Mol. Cell. Biol. 11: 5410-5416.

Zillmann, M., Gorovsky, M.A., and Phizicky, E.M. 1992. HeLa cells contain a 2 '-phosphate-specific phosphotransferase similar to a yeast enzyme implicated in tRNA splicing. J. Biol. Chem. 267: 10289-10294.

Zofallova, L., Guo, Y., and Gupta, R. 2000. Junction phosphate is derived from the precursor in the tRNA spliced by the archaeon Haloferax volcanii cell extract. RNA 6: 1019-1030. 

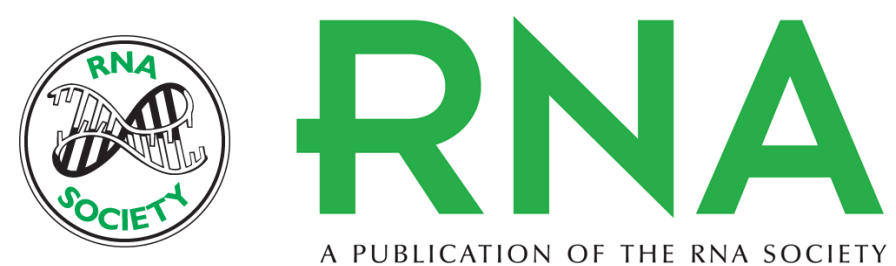

A PUBLICATION OF THE RNA SOCIETY

\section{An intact unfolded protein response in Trpt1 knockout mice reveals phylogenic divergence in pathways for RNA ligation}

Heather P. Harding, Jeremy G. Lackey, Hao-Chi Hsu, et al.

RNA 2008 14: 225-232

References This article cites 42 articles, 23 of which can be accessed free at:

http://rnajournal.cshlp.org/content/14/2/225.full.html\#ref-list-1

\section{License}

Email Alerting Receive free email alerts when new articles cite this article - sign up in the box at the Service top right corner of the article or click here. 